\title{
Treatment of acute myocardial infarction with
} intracoronary administration of autologous

\author{
bone marrow cells
}

The ASTAMI study

\section{By Ketil Lunde}

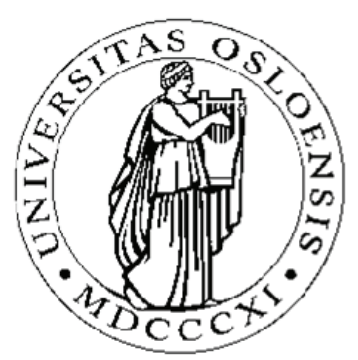

Department of Cardiology

Rikshospitalet University Hospital

University of Oslo

Oslo, Norway

2008 
(C) Ketil Lunde, 2008

Series of dissertations submitted to the

Faculty of Medicine, University of Oslo

No. 659

ISBN 978-82-8072-762-6

All rights reserved. No part of this publication may be reproduced or transmitted, in any form or by any means, without permission.

Cover: Inger Sandved Anfinsen.

Printed in Norway: AiT e-dit AS, Oslo, 2008.

Produced in co-operation with Unipub AS.

The thesis is produced by Unipub AS merely in connection with the thesis defence. Kindly direct all inquiries regarding the thesis to the copyright holder or the unit which grants the doctorate.

Unipub AS is owned by

The University Foundation for Student Life (SiO) 



\section{CONTENTS:}

Acknowledgments 1

List of papers: $\quad 5$

Abbreviations: $\quad 7$

Definitions: 9

Motivation: $\quad 11$

Myocardial regeneration $\quad 11$

Bone marrow cells for myocardial regeneration $\quad 12$

The ASTAMI study:

$\begin{array}{ll}\text { Steering committee } & 16\end{array}$

Aims of the study 16

Methods 17

Bone marrow aspiration and processing $\quad 19$

Intracoronary injection of mBMC 21

Assessment of LV function $\quad 21$

Repeatability 23

Coronary angiography $\quad 27$

Exercise testing and quality of life 27

GCP inspection $\quad 27$

Monitoring of quality data $\quad 28$

Sample size and statistics $\quad 28$

Summary of results: $\quad 30$

Paper I 30

Paper II 30

Paper III 31

Paper IV $\quad 32$

Discussion: $\quad 33$

Methodological considerations $\quad 33$

Internal validity $\quad 35$

External validity $\quad 39$

Comparison with other studies $\quad 41$

General aspects $\quad 44$

Perspectives: $\quad 49$

Conclusion: $\quad 51$

Reference list: 


\section{ACKNOWLEDGMENTS}

The present work was carried out at the Department of Cardiology, Rikshospitalet University Hospital in the period September 2003 - August 2007, and completed in 2008. A research fellowship from The Norwegian Council on Cardiovascular diseases was the primary source for financial support. Grants from Inger and John Fredriksen`s Heart Foundation and a research fellowship from Medinnova AS were important contributions. Furthermore, I have received grants from The Norwegian Society of Cardiology and from Dr. Alexander Malthe`s legacy. I am grateful to them all.

One late afternoon on the ward in 2003, I was balancing today`s heap of medical reports as I was halted by dr Kolbjørn Forfang. "Are you interested in medical research?" he asked me. I couldn't at the time imagine the consequencies of his enquiry, but surely, life would have been poorer if I had declined. A few months earlier, we had met at the crack of dawn one Sunday in New York to witness Bernardo Nadal-Ginard`s presentation about myocardial regeneration by bone marrow cells. I was unaware that since then, Forfang was already teamed up with dr Svend Aakhus preparing the Autologous Stem cell Transplantation in Acute Myocardial Infarction (ASTAMI) study. This thesis confirms that I took advantage of the good opportunity and agreed to join the ASTAMI study as a research fellow.

I was most fortunate to have Svend as my primary supervisor. His rare combination of good clinical skills, his expertise in cardiac imaging, comprehensive knowledge about medical research and maybe most important, his vast common sence has been most 
useful during my work with this thesis. Thank you for all time spent during conduction of the study, preparation of presentations and manuscripts, and last but not least, for the general support. Svend, I admire you for being a person who care.

Kolbjørn`s position as a grand old man in Norwegian cardiology made him the natural choice as the chairman of the ASTAMI steering committee. The initiation of the study would not have been possible without his extensive merits in clinical research and his widespread connections. His never-ending enthusiasm has been most important. Thank you for all support, and for trusting me as fellow on the ASTAMI study.

I am grateful to the other members of the ASTAMI steering committee, professor Harald Arnesen and dr Arild Mangschau at Department of Cardiology, Ullevål University Hospital, dr Knut Endresen at Department of Cardiology and dr Torstein Egeland at the Institute of Immunology (IMMI) at Rikshospitalet and professor Arnfinn Ilebekk at the Institute for Experimental Medical research, University of Oslo. Dr Jan E Brinchmann at IMMI has been important for all parts of cell processing. Thank you for sharing time and knowledge.

Professor Otto A. Smiseth has been head of the Department of Cardiology and the Heart and Lung Clinic at Rikshospitalet during conduction of the study, and he has also been my co-supervisor. I really appreciate that you made it possible to conduct the study at your institution. 
The ASTAMI study involved several departments at several institutions, and the study would never have been completed without the contribution of a large number of people. I am indebted to all co-authors and co-workers, and I hope those of you not mentioned by name will forgive me. A special thank to Svein Solheim, my associate research fellow at Ullevål, to dr Eli Taraldsrud at IMMI for cell preparation, to drs Lorentz Brinch and Yngvar Fløisand for bone marrow aspirations, to drs Jan Gunnar Fjeld, Hans-Jørgen Smith and Einar Hopp for cardiac imaging, to professor Jan Peder Amlie for signalaveraged ECG, to Michael Abdelnoor for general statistical support and to Magne Thoresen for statistical advice. Dr Torbjørn Moum was irreplaceable for analysis of quality of life data. I will also thank Drs Knut Rasmussen, University Hospital of North Norway, Rune Wiseth, University Hospital of Trondheim and Lars Wallentin, Uppsala University Hospital who constituted the data and safety monitoring board. I appreciate the support from the staff at the Department of Cardiology at Rikshospitalet, which made it possible to perform the extensive and time-consuming examination protocol during hectic days on the ward. I thank Elin Kjekshus and Cecilia Guevara for blood test samplings and for taking care of the patients during follow-up. I am also grateful to the patients for time and effort spent, and the courage needed to participate in the study.

During these years, I have enjoyed sharing office with dr Eirik Pettersen, who has provided valuable assistance on technical issues, text editing and support during hardtimes. 
Hilde Nordby was initially engaged as research nurse, and started out energetic and enthusiastic about the study. Unfortunately, her tragic early passing away deprived us the pleasure of finishing the project together.

Being a research fellow means freedom, which undoubtedly is a benefit for family life. Being a research fellow also means late work hours, travelling and loss of income, which is likely to have the opposite effect. I am grateful to my parents and to my parents in law for help and assistance during these years. Furthermore, the absent-minding fellow may not be the ideal husband and father. Thank you Gro Merete, for love, care, understanding and support. Thank you Oda, Tuva and Trym. I know I am priviledged to have you. 


\section{LIST OF PAPERS}

I Lunde K, Solheim S, Aakhus S, Arnesen H, Abdelnoor M, Forfang K. Autologous stem cell transplantation in acute myocardial infarction: The ASTAMI randomized controlled trial. Intracoronary transplantation of autologous mononuclear bone marrow cells, study design and safety aspects. Scandinavian Cardiovascular Journal 2005;39:150-158.

II Lunde K, Solheim S, Aakhus S, Arnesen H, Abdelnoor M, Egeland T, Endresen K, Ilebekk A, Mangschau A, Fjeld JG, Smith HJ, Taraldsrud E, Grøgaard HK, Bjørnerheim R, Brekke M, Müller C, Hopp E, Ragnarsson A, Brinchmann JE, Forfang K. Intracoronary injection of mononuclear bone marrow cells in acute myocardial infarction. New England Journal of Medicine 2006;355:1199-1209.

III Lunde K, Solheim S, Aakhus S, Arnesen H, Moum T, Abdelnoor M, Egeland T, Endresen K, Ilebekk A, Mangschau A, Forfang K. Exercise capacity and quality of life after intracoronary injection of autologous mononuclear bone marrow cells in acute myocardial infarction: Results from the autologous stem cell transplantation in acute myocardial infarction (ASTAMI) randomized controlled trial. American Heart Journal 2007;154:710.e1-710.e8. 
IV Lunde K, Solheim S, Forfang K, Arnesen H, Brinch L, Bjørnerheim R, Ragnarsson A, Egeland T, Endresen K, Ilebekk A, Mangschau A, Aakhus S. Anterior myocardial infarction with acute percutaneous coronary intervention and intracoronary injection of autologous mononuclear bone marrow cells. Safety, clinical outcome, and serial changes in left ventricular function during 12 months follow-up. Journal of the American College of Cardiology 2008;51:674-6. 


\section{ABBREVIATIONS}

\begin{tabular}{|c|c|}
\hline $\mathrm{ACE}$ & Angiotensin-converting enzyme \\
\hline ANCOVA & Analysis of covariance \\
\hline ASTAMI & Autologous stem cell transplantation in acute myocardial infarction \\
\hline AMI & Acute myocardial infarction \\
\hline $\mathrm{BMC}$ & Cells derived from bone marrow \\
\hline $\mathrm{CHF}$ & Congestive heart failure \\
\hline $\mathrm{CPC}$ & Circulating progenitor cells \\
\hline $\mathrm{CRF}$ & Case report formulas \\
\hline EPC & Endothelial progenitor cells \\
\hline ESC & Embryonic stem cells \\
\hline FLASH & turbo fast low-angle shot \\
\hline GCP & Good clinical practice \\
\hline $\mathrm{G}-\mathrm{CSF}$ & Granylocyte colony-stimulating factor \\
\hline GMP & Good manufacturing practice \\
\hline HSC & Hematopoietic stem cells \\
\hline LAD & Left anterior descending (coronary artery) \\
\hline LV & Left ventricle \\
\hline LVEF & Left ventricular ejection fraction \\
\hline LVEDV & Left ventricular end-diastolic volume \\
\hline LVESV & Left ventricular end-systolic volume \\
\hline NoMA & Norwegian Medicines Agency \\
\hline
\end{tabular}




$\begin{array}{ll}\text { MAPC } & \text { Multipotent adult progenitor cells } \\ \text { mBMC } & \text { Mononuclear cells derived from bone marrow } \\ \text { MRI } & \text { Magnetic resonance imaging } \\ \text { MSC } & \text { Mesenchymal stem cells / multipotent mesenchymal stromal cells } \\ \text { PCI } & \text { Percutaneous coronary intervention } \\ \text { QCA } & \text { Quantitative coronary angiography } \\ \text { RUH } & \text { Rikshospitalet University Hospital } \\ \text { SD } & \text { Standard deviation } \\ \text { SF-36 } & \text { Short Form 36 } \\ \text { SP cell } & \text { Side population cells } \\ \text { SPECT } & \text { Single-photon-emission computed tomography } \\ \text { STEMI } & \text { ST-elevation myocardial infarction } \\ \text { TrueFISP } & \text { True fast imaging with steady-state free precession } \\ \text { UiO } & \text { University of Oslo } \\ \text { UUH } & \text { Ullevål University Hospital } \\ \text { WMSI } & \text { Wall motion score index }\end{array}$




\section{DEFINITIONS}

The classical definition of a stem cell requires two criteria to be fulfilled

1. The ability of self-renewal.

2. The ability to differentiate into specialized cell types.

This means that a stem cell can undergo mitotic cell division to two identical daughter cells with identical properties as the mother cell, or to one cell resembling its mother and to another more differentiated cell. Alternatively, both daughter cells can be more differentiated. The more mature descendants of the mother cell can further divide to give rise to a progeny of mature cells with more specialized properties.

\section{Hierarchy of potency}

Stem cells can be classified according to their potency for differentiation:

\section{Totipotent stem cells}

The fertilized oocyte (the zygote) and the descendants of the first two cell divisions are totipotent stem cells. This means that they are able to form both the embryo and the placenta. 
Pluripotent stem cells

During embryogenesis, the totipotent stem cells form a hollow ball of cells (the blastocyst) which gives rise to the placenta, and the inner cell mass which contains the embryonic stem cells (ESC). ESC are pluripotent, i.e. they are able to differentiate to cells of all three germ layers, the endoderm, the mesoderm and the ectoderm, but not the placenta.

\section{Multipotent stem cells}

The traditional definition of multipotent stem cells is the capability of differentiation to a limited range of cell lineages. The hematopoietic stem cells (HSC) are multipotent.

\section{Unipotential stem cells}

These cells are capable of differentiation to one specific cell type. One example is the myoblast. These cells are often referred to as progenitor cells, e.g. endothelial progenitor cells (EPC).

\section{Embryonic versus adult stem cells}

As stated above, the ESC comprise the inner cell mass of the blastocyst. Adult stem cells are stem cells found in developed tissues and can be found both in children and adults. Adult stem cells are often referred to as somatic stem cells. 


\section{MOTIVATION}

Cardiovascular disease is a major global health problem, accounting for approximately 17 million deaths worldwide each year, and the majority of these deaths are caused by ischemic heart disease ${ }^{1}$. Modern reperfusion strategies with fibrinolyis or percutaneous intervention (PCI), and medical treatment with antiplatelet agents, beta-blockers, ACEinibitors and/or angiotensin receptor blockers and statins have improved prognosis for patients with myocardial infarction ${ }^{2}$. After acute occlusion of a coronary artery, myocardial infarction can be aborted when reperfusion is obtained within 30 minutes $^{3}$. However, since the majority of these patients will receive reperfusion later, most will develop myocardial infarction with necrotic myocardial cell death through oncosis and to a lesser degree apoptosis ${ }^{4}$. Especially patients with large, transmural infarctions are at risk of remodeling, characterized by a general change in ventricular size, geometry and function, and the development of congestive heart failure $(\mathrm{CHF})^{5,6}$. Patients diagnosed with CHF have a dismal prognosis with an expected 1-year mortality of $20 \%{ }^{7}$. None existing therapy can provide myocardial repair, and new treatment options with potential for myocardial regeneration are needed.

\section{MYOCARDIAL REGENERATION}

The long-lasting paradigm that the human heart cannot regenerate has recently been challenged by several observations. Adult mature cardiomyocytes are terminally differentiated and have either no or limited regenerative capacity since they are unable to 
reenter the cell cycle ${ }^{8}$. However, a low-grade continuous cardiomyocyte death by apoptosis seem to be a normal phenomenon in the human heart ${ }^{9}$, and even conservative estimates of normal cell death indicate that the entire human heart would disappear within a few decades if there was no regeneration ${ }^{10}$. Currently, there is growing evidence that there is a continuous low-rate turn-over of cardiomyocytes throughout life ${ }^{11}$. Several stem cell populations have been identified within the mammalian (including the human) heart ${ }^{12}$, and the numbers of replicating cells within the myocardium are increased in pathological conditions like ischemic and idiopathic cardiomyopathy ${ }^{13}$, pressure overload $^{14}$ and after myocardial infarction ${ }^{15}$. Cardiac stem cells may be remnants from embryonic development maintained in specific niches within the heart. However, several observations indicate that the bone marrow is involved in cardiac repair, and that cardiac stem cells may derive from the bone marrow ${ }^{16,17}$.

\section{Bone marrow cells for myocardial regeneration}

At the turn of the millennium, the regenerative capacity of the bone marrow was shown to be greater than previously thought. HSC are the best characterized adult stem cells. They are multipotent, and have the ability to differentiate to several types of bone marrow and blood cells. HSC transplantations have been used for more than 50 years to repopulate the bone marrow of ablated recipientes ${ }^{18}$. However, new data indicated that HSC and other cells derived from bone marrow (BMC) possessed a property of developmental plasticity. This means an ability to differentiate across boundaries of lineage, tissue or germ layer and acquire an unexpected phenotype in a process called 
transdifferentiation. According to the environment where the cells were placed, BMC were shown to transdifferentiate into cells of such different organs as brain ${ }^{19}, \operatorname{liver}^{20}$ and skeletal muscle ${ }^{21}$. In 2001, BMC were found to transdifferentiate to endothelial cells, smooth muscle cells and cardiomyocytes, and to regenerate the myocardium in experimental models of acute myocardial infarction (AMI) in mice 22,23 .

The bone marrow contains a hierarchy of stem cell populations with varying potential for differentiation. The multipotent adult progenitor cells (MAPC) are primitive cells with the potential for in-vitro differentiation to cell types of all three germ layers after being injected into the early blastocyst ${ }^{24}$. These cells may be the precursors of the hemangioblast which typically express the surface markers CD34 and CD133 25 , and the mesenchymal stem cells / multipotent mesenchymal stromal cells (MSC). MSC are primarily characterized by their ability to adhere to plastic in culture and their multipotent differentiation capacity in vitro ${ }^{26}$. The hemangioblast is the precursor of the HSC, which also typically express CD34 and $\mathrm{CD} 133^{27}$, and to the EPC. Characterisation of EPC is not uniform, but some features include expression of CD34 and the receptor for vascular endothelial growth factor, VEGFR2(KDR), the lack of markers seen on fully differentiated endothelial cells, and the potential to form mature endothelial cells in culture $^{28}$. Circulating cells with similar properties are often referred to as circulating progenitor cells (CPC). In addition a stem cell population of side population (SP) cells, characterized by their ability to expel the Hoechst dye 33342 has been identified. SP-cells may have the ability to reconstitute the entire bone marrow after single cell grafting ${ }^{29}$. All these bone marrow cell populations are mononucleated and they are scarce. Multipotent 
HSC constitute approximately $0.01 \%$ of all blood cells within the bone marrow ${ }^{30}$, and the amount of MSC is probably 10 -fold less ${ }^{31}$.

Studies in patients after sex-mismatched bone marrow or cardiac transplantation support that BMC are involved in cardiac repair. In such studies, the sex-chromosomes can be used to identify cells of non-cardiac origin. In male recipients of female hearts, large numbers of XY-chromosome positive endothelial, smooth muscle cells and cardiomyocytes have been found in the transplanted hearts ${ }^{32}$. Similarly, in female recipients of male hearts, XX-chromosome positive cardiomyocytes were identified ${ }^{33}$. The origin of these cells is not clarified, and it has been postulated that intrinsic cardiac stem cells from remniscent atrial tissue may have populated the transplanted heart.

However, XY-chromosome positive cardiomyocytes ${ }^{34}$ and smooth muscle cells ${ }^{35}$ have been identified in female recipients of male bone marrow, suggesting that circulating BMC have homed to the heart and transdifferentiated. Thus, regeneration of the heart by BMC may be a naturally occurring phenomenon that handles the need for the continuous, low-grade turn-over of cardiac cells. However, this mechanism is obviously insufficient in the setting of acute large cell loss, since myocardial infarction heals with scar formation $^{36}$. Therefore, attempts to enforce BMC mediated cardiac repair by direct transplantation of cells to the heart were tempting, and clinical studies were started promptly after the publication of the initial studies in rodents ${ }^{22,23,37}$. 
In 2002, Strauer et al described a technique for intracoronary injection of BMC in patients with AMI after acute reperfusion with $\mathrm{PCI}^{38}$. The same technique was used for injection of either BMC or CPC in the TOPCARE-AMI study ${ }^{39}$. These studies indicated that the treatment was feasible and safe, and the results indicated reduced infarct size and improved left ventricle (LV) function and perfusion after BMC treatment. However, interpretation of results was hampered by the unrandomized study designs and small patient groups.

\section{THE AUTOLOGOUS STEM CELL TRANSPLANTATION IN ACUTE MYOCARDIAL INFARCTION (ASTAMI) STUDY}

On this background, during autumn 2002, we started to explore the possibility for a Norwegian, randomized clinical trial with intracoronary injection of autologous mononuclear BMC (mBMC) in patients with AMI. It was soon realized that several departments at several institutions needed to be involved to conduct such a trial. A steering committee with members from Rikshospitalet University Hospital (RUH), Ullevål University Hospital (UUH) and the University of Oslo (UiO) was founded, and the protocol for the ASTAMI study was prepared. Drs Knut Rasmussen, Lars Wallentin and Rune Wiseth agreed to participate in a data and safety monitoring board. Dr Svein Solheim was engaged as research fellow at UUH, and dr Ketil Lunde at RUH. The protocol was approved by the regional ethics committee on June 3, 2003. The use of mBMC in the ASTAMI study was subject to the Medicines for Human Use (Clinical Trials) regulations (CPMP/ICH/291/95) on Good Clinical Practice (GCP), and needed 
approval by The Norwegian Medicines Agency (NoMA). A revised protocol was approved by NoMa Agency on September 3, 2003. The first patient was included in the study on September 11, 2003. Application to The Data Inspectorate was sent on September 9, 2003 and after approval on January 28, 2004, collected data could be entered into the electronic database.

\title{
Steering committee
}

Kolbjørn Forfang (Chair) Department of Cardiology, RUH

Harald Arnesen Department of Cardiology, UUH

Torstein Egeland Institute of Immunology, RUH

Knut Endresen Department of Cardiology, RUH

Arnfinn Ilebekk Institute for Experimental Medical Research, UiO

Arild Mangschau Department of Cardiology, UUH

Svend Aakhus Department of Cardiology, RUH

\begin{abstract}
Aims of the study
We wanted to investigate whether intracoronary injection of autologous $\mathrm{mBMC}$ in patients with AMI resulted in clinically important effects on:

1) LV function. The primary aim was to examine whether mBMC treatment resulted in at least 5\% improvement of the change in left ventricular ejection fraction (LVEF) from baseline to 6 months follow-up compared to controls.
\end{abstract}


2) Exercise capacity assessed as peak VO2 and quality of life assessed by the Short Form 36 (SF-36) health survey (secondary aim).

3) Infarct size (additional aim).

Furthermore, to examine whether any such changes were correlated to the number of mBMC or subpopulations injected. Finally, to assess the safety of this treatment during 12 months follow-up. In the protocol, an additional aim was to assess the effects of mBMC treatment on biochemical signaling responses. The latter issue is not a part of the present thesis.

\section{Methods}

\section{Design}

The ASTAMI study was an open-labeled, randomized clinical trial. A sham procedure with bone marrow aspiration and intracoronary injection of placebo medium in control patients was considered unethical, since this would expose these patients to the risks of the procedures without the possibility for a beneficial effect of cell injections. Major parts of the protocol are presented in paper I, and in the appendix of paper II. Here, the protocol is presented in short, and some issues are further elaborated. All patients with ST-segment elevation acute myocardial infarction (STEMI) admitted for acute PCI at RUH in the period September 3, 2003 to May 4, 2005, and at UUH between mid September, 2003 and May 4, 2005 were screened for inclusion in the study, and eligible patients were invited to participate. 
Inclusion criteria: All criteria must be fulfilled.

- Age between 40 and 75 years.

- Acute anterior wall myocardial infarction with a history $>3$ hours and $<12$ hours.

- ST elevation infarction (WHO ECG criteria).

- Angiographic criteria: Occlusion (TIMI flow $0-1$ ) of the left anterior descending (LAD) coronary artery proximal to the second diagonal branch.

- Successful primary or rescue PCI (TIMI flow 2 or better).

- Echocardiographic criteria: Evidence for anterior wall infarction as judged by hypo- or akinesia in more than 2 adjacent anterior wall segments.

- Enzymatic criteria: CKMBmass $>3$ times upper normal value.

Exclusion criteria:

- Previous myocardial infarction with established significant Q waves on ECG.

- Cardiogenic shock.

- Hemodynamic instability necessitating intraaortic balloon pump treatment.

- Permanent pacemaker or other contraindications to magnetic resonance imaging (MRI).

- Stroke with significant sequela.

- Short life expectancy due to extra cardiac reason, e.g. chronic obstructive lung disease, disseminated malignant disease, or other reason.

- Uncontrolled endocrinological disturbance.

- Anamnestic indications for significant mental disorder, including dementia.

- Established HIV or hepatitis B infection.

- Any condition which interferes with patients possibility to comply with the protocol. 
Protocol change

Since there was widespread use of primary or facilitated thrombolysis before transfer for acute PCI, many patients had more than TIMI I flow in the LAD before PCI. Because the logistics for transfer of AMI patients for acute PCI in Norway is effective, many patients received PCI less than 3 hours after symptom onset. Nevertheless, many of these patients developed extensive infarctions. Therefore, on October 8, 2003, inclusion criteria \#4 was changed to: Acute anterior wall myocardial infarction with a history $>2$ hours and $<12$ hours. On January 27, 2004, inclusion criteria \#3 was changed to: Angiographic criteria: Significant stenosis proximal to the second diagonal branch

After obtaining written informed consent, patients were randomized 1:1 to either the treatment group or the control group by a permuted block randomization which was stratified according to study center. The block size was 4. Center for Clinical Research at UUH provided consecutively numbered, sealed envelopes.

In total, 1608 patients were screened for inclusion in the study (Figure 2, paper II).

\section{Bone marrow aspiration and processing of mononuclear bone marrow cells}

The protocol for bone marrow aspiration and preparation was based on standardized methods used in the field of hematology ${ }^{40}$. Approximately $50 \mathrm{ml}$ bone marrow was considered the maximum volume of bone marrow feasible for aspiration in local 
anaesthesia, and a similar volume had been used in the previous trials which suggested an effect of intracoronary administration of $\mathrm{mBMC}^{38,39}$. The bone marrow underwent density gradient centrifugation on Ficoll-isopaque (Lymphoprep ${ }^{\mathrm{TM}}$, Axis-Shield, Oslo, Norway) for isolation of mononuclear cells, and after washing, cells were stored in $0.9 \%$ $\mathrm{NaCl}$ with $20 \%$ autologous heparin plasma. All cell processing were performed at the Exvivo cell laboratory at the Institute for Immunology at RUH under Good Manufacturing Practice (GMP) regulations. In the cell processing protocol sent to the NoMA, it was planned to use the cell culture medium RPMI-1640 (Gibco®), Invitrogen Ltd, Paisley, UK) for cell storage. Due to insufficient safety data for human use, RPMI-1640 was not approved by the NoMA, and therefore replaced with autologous heparin-plasma in the final protocol. NoMA found documentation for Lymphoprep ${ }^{\mathrm{TM}}$ satisfactory.

\section{Protocol change}

In the original protocol, it was allowed to perform the intracoronary cell injections either on the same day as bone marrow aspiration and preparation of $\mathrm{mBMC}$, or to store the prepared mBMC overnight before injections. All aspirates were tested for bacterial contamination. In one mBMC sample from a patient with aspiration, preparation and intracoronary injection on the same day, contamination with staphylococci was discovered the next day, and the protocol was changed. After November 3, 2005, cells could only be delivered from the Institute of Immunology after preliminary testing of overnight bacteriological specimens were found negative. 


\section{Intracoronary injection of mBMC}

A PCI stop-flow technique first described by Strauer $e t a l^{38}$ was used for intracoronary injection of $\mathrm{mBMC}$ either the same day, or the day following bone marrow aspiration. After intubation of the left coronary ostium with a 6 French catheter, a $0.5 \mathrm{~mm}$ oversized over-the-wire balloon catheter was advanced to the proximal part of the culprit lesion stent in the LAD. One third of the cell solution was injected during $90 \mathrm{~s}$ balloon inflation and no-flow, followed by 5 min reperfusion. The procedure was repeated twice.

\section{Assessment of LV function}

We used ECG-gated single-photon-emission computed tomography (SPECT), echocardiography and MRI to obtain LV end-diastolic (LVEDV) and end-systolic (LVESV) volumes. By each imaging modality, LVEF was calculated as:

(LVEDV - LVESV) / LVEDV x 100\%.

Different imaging modalities have different strengths and weaknesses ${ }^{2}$, and the rationale for the use of three imaging modalities was both the need for a comprehensive evaluation of all aspects of LV function, and the possibility for methodological comparisons. The latter issue is not a part of this thesis. 
SPECT

SPECT was the prespecified primary imaging modality for assessment of LV function, and the change in LVEF obtained by SPECT was the primary end point of the study. SPECT was chosen for several reasons. Data for variability of LVEF with scintigraphic techniques had previously been obtained in 93 patients with myocardial infarction at UUH. The estimated standard deviation (SD) for LVEF was $8.3 \%$, and was used for calculating study sample size. Furthermore, SPECT recordings could be obtained at baseline at both centers, and SPECT is probably the best validated method for assessment of infarct size ${ }^{41}$. SPECT recordings were obtained at baseline (4.0 \pm 1.4 days) and repeated after 6 months.

\section{Echocardiography}

2-dimensional echocardiograpy was used for supplementary information on global LV function. Multiple parasternal and apical imaging planes were used to obtain the wall motion score index (WMSI) for assessment of regional LV function. Echocardiograms were obtained at baseline (4.5 \pm 1.1 days), and repeated after 3, 6 and 12 months, allowing the assessment of serial changes in LV function. Results obtained by Doppler echocardiography, tissue velocity imaging and dobutamine stress-echocardiograpy are not a part of this thesis.

\section{MRI}

MRI was used for supplementary information on LV global function and infarct size with gadolinium late enhancement contrast imaging. For two reasons, baseline recordings for 
MRI were obtained 2-3 weeks after the acute infarction. Due to tissue edema, infarct size is overestimated when MRI is obtained in the acute phase of a myocardial infarction ${ }^{42}$. Furthermore, the capacity for MRI is limited, and it was considered impossible to perform all recordings in the acute phase. Since all MRI was obtained at RUH, the transfer of patients from UUH in the acute phase would also have caused logistic problems. MRI was repeated at 6 months.

A detailed description of cell processing and transfer, and cardiac imaging is provided in the appendix of paper II, which was published with the full text of the paper at www.nejm.org ${ }^{43}$.

\section{Repeatability}

Re-read repeatability of LVEF was assessed several months after the original analyses in a random subset of 25 patients` 6 months recordings. These patients were chosen for repeatability studies since they also participated in a study for assessment of LV volumes with the use of 3D-echocardiography where they were included on a consecutive basis ${ }^{44}$.

\section{SPECT}

Two technicians who were unaware of treatment allocation analyzed all SPECT recordings en-bloc, and the same technician analyzed baseline and 6 month recordings for the same patient. Technician A analyzed 53 pairs of recordings, and technician B 47. In 
the repeatability study, technician A re-read 8 recordings, and technician B 17 recordings. The Bland-Altman plot is presented in Figure 1.

\section{Figure 1}

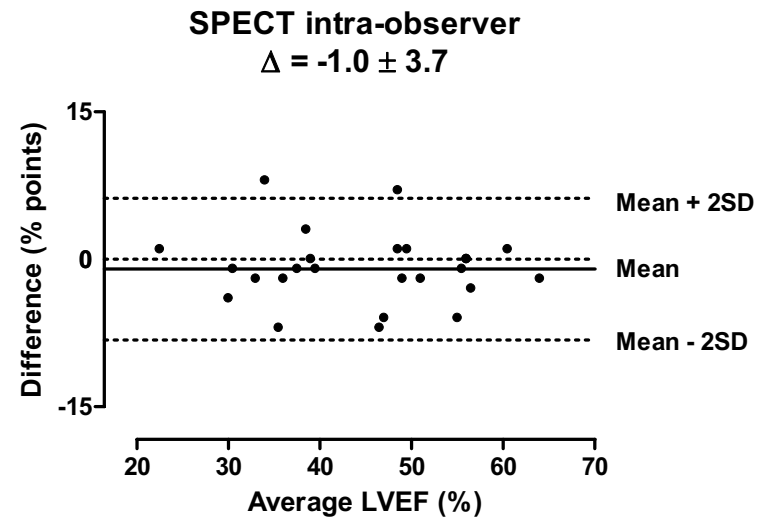

Echocardiography

Echocardiograms were obtained by several investigators, blinded and then analyzed enbloc by a single investigator (KL). The Bland-Altman plot for intra-observer variability is presented in Figure 2.

Figure 2

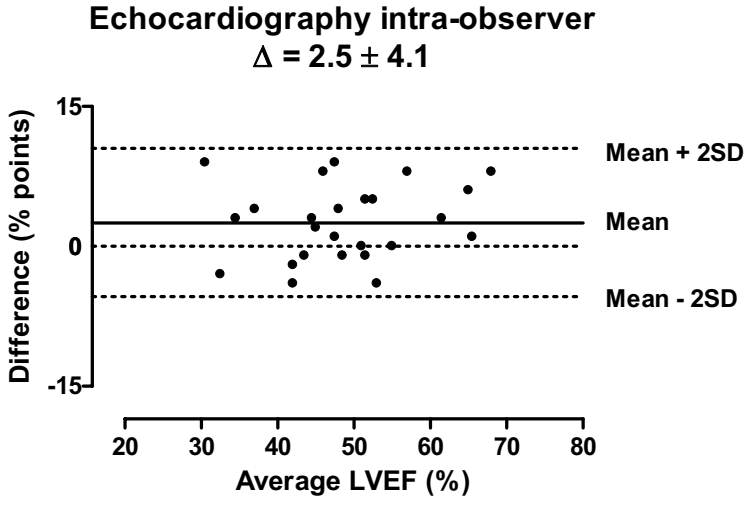


MRI

MRI was analyzed on a consecutive basis by two investigators who were unaware of treatment allocation. Recordings obtained at 6 months were not necessarily analyzed by the investigator who performed the analysis at 2-3 weeks. Therefore, interobserver variability was considered of major importance. Two methods for obtaining MRI was used, turbo fast low-angle shot (FLASH) and true fast imaging with steady-state free procession (trueFISP). The same technique was used for the same patient at 2-3 weeks and at 6 months. Paired data were obtained for 63 patients with FLASH and 24 with trueFISP. To obtain repeatability data for 25 patients by each method, the MRI investigators included further patients over the 25 patients in the SPECT and echocardiography repeatability study on an arbitrary basis. Bland-Altman plots of interobserver variability by the two methods are shown in Figure 3. 
Figure 3

\section{MRI FLASH inter-observer \\ $\Delta=0.4 \pm 7.0$}

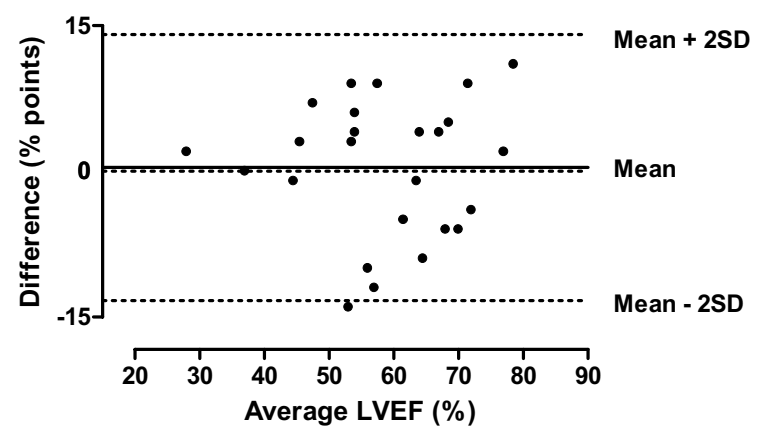

MRI trueFISP inter-observer

$\Delta=0.3 \pm 2.2$

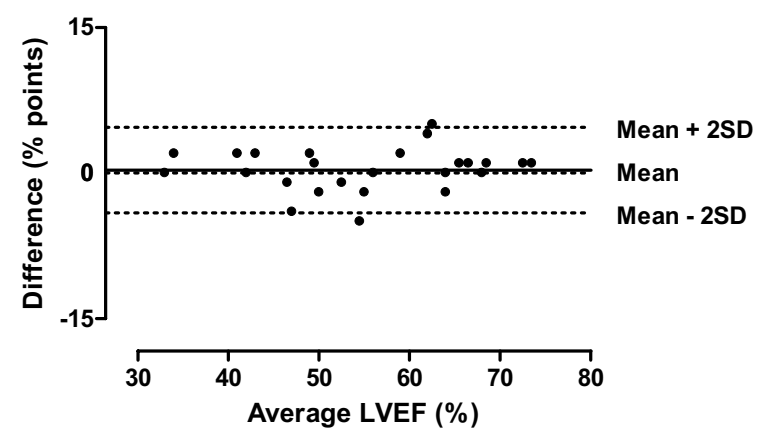




\section{Coronary angiography}

All patients were treated with PCI with stenting of culprit lesion in the proximal or mid portion of the LAD. Stent type was chosen according to the preference of the PCI operator. Complete angiograms were obtained before stenting, and repeated after 6 months, and quantitative coronary angiography (QCA) on the LAD were performed at both occations with the use of CMS ${ }^{\text {TM }}$ Medis software (Sectra Imtec AB, Linkøbing, Sweden). All angiograms were analyzed en-bloc by a single investigator (AR) who was unaware of treatment allocation.

\section{Exercise testing and quality of life}

Patients performed maximal, symptom-limited bicycle spiroergometry and answered the Norwegian version 1.2 of the SF-36 health survey 2-3 weeks and 6 months after the acute event (see methods in paper III for a detailed description).

\section{GCP inspection}

On September 27, 2004, NoMA notified GCP-inspection of the ASTAMI study. The inspection was founded on $\S 3$ of Act no. 132 of December 4, 1992 relating to Medicines etc. (Medicines Act), the Regulation relating to clinical trials on medical products for human use of June 18, 1999 and/or September 24, 2003, and the Personal Data Act of February 21, 2003. Three GCP-inspectors from the NoMA carried out full-time 
inspection at UUH on November 9-10, 2004 and at RUH on November 11-12, 2004. The aim of the inspection was to assess if the systems for maintaining the study was taken care of. Raw-data for 10 patients at each center were checked. All patients were found to be eligible according to the inclusion and exclusion criteria, and data in the case report formulas $(\mathrm{CRF})$ did not differ from the raw-data.

Plan for amendment of discrepancies was sent from UUS on March 18, 2005 and from RUH on April 8, 2005. The NoMA approved the plan and closed the GCP inspection for UUH on March 30, 2005, and for RUH on April 18, 2005.

\section{Monitoring of data quality}

Ragnhild Kleve at the Department of Preventive Cardiology at UUH monitored data quality, i.e. the transition of raw-data via paper version CRF to the electronic database. Data for LV volumes and LVEF by all methods were controlled in all patients. All data in the CRF were controlled for a random subset of 10 patients at RUH and 8 at UUH. There were no discrepancies for the LV function data, and data quality was generally high.

\section{Sample size and statistics}

A clinically important treatment effect of $\mathrm{mBMC}$ treatment was estimated to be a difference between groups of 5\% points for the change in LVEF from baseline to 6 months. With a significance level (Type I error or $\alpha$ ) at $5 \%$, a Type II error or $\beta$ at $20 \%$ 
which gives a power (1- $\beta$ ) of $80 \%$, and an estimated SD of LVEF measurement of $8.3 \%$ by scintigraphic techniques, it was calculated that 45 patients were needed in each group. To allow for some drop-outs, it was decided to include a total of 100 patients. All data were analyzed and presented according to the intention-to-treat principle. The statistical methods used are presented specifically in each paper. 


\section{SUMMARY OF RESULTS}

\section{Paper I}

This paper presents the design of the ASTAMI study. The paper also includes a study on safety aspects of bone marrow aspiration and intracoronary mBMC injections. Data obtained by August 2004 were included. At that time, 1004 patients were screened for inclusion and 49 were included in the study, 24 were randomized to the mBMC group and 25 to the control group. There were no complications related to the bone marrow aspiration procedure, but contamination with coagulase-negative staphylococci was discovered in one aspirate before intracoronary injection, and the procedure was repeated. In the mBMC group, $20(87 \%)$ patients experienced chest pain during cell injections under balloon inflation, and $16(70 \%)$ had ischemic ST-segment changes on the ECG defined as $\geq 1 \mathrm{~mm} \mathrm{ST}$-segment depression or elevation at the J-point $+60 \mathrm{~ms}$. There were no reinfarctions after cell injections as assessed by new elevation of CK-MB mass. All patients were alive, and the adverse event rate was generally low and not different in the groups.

\section{Paper II}

This paper presents the main results of the ASTAMI study. A total of 101 patients were included in the study, one patient was excluded owing to early heart transplantation, and there were 50 patients in both the $\mathrm{mBMC}$ and the control group. For varying reasons, 3 
patients in the mBMC group did not receive mBMC injections. There were no differences between groups in patients baseline characteristics, with a mean age of $57 \pm 9$ years, a median time from symptom onset to PCI of 210 minutes (interquartile range 180 to 330) and a median value for maximum CK-MB mass of $369 \mu \mathrm{g} / \mathrm{L}$ (interquartile range 220 to 444). After 6 months follow-up, there was a similar improvement in global LV function in both groups. With the use of SPECT, LVEF increased with $8.1 \pm 11.2 \%$ in the mBMC group and with $7.0 \pm 9.6 \%$ in the control group $(\mathrm{P}=0.77$ for difference between groups). With the use of echocardiography, LVEF increased with $3.1 \pm 7.9 \%$ in the mBMC group and with $2.1 \pm 9.2 \%$ in the control group $(\mathrm{P}=0.70)$. With the use of MRI, LVEF increased with $1.2 \pm 7.5 \%$ in the mBMC group and with $4.3 \pm 7.1 \%$ in the control group $(\mathrm{P}=0.054)$. The change in LVEF was not correlated to the number of injected mBMC. There were no differences between groups for the change in LVEDV and infarct size. All patients were alive, the rate of adverse events was generally low and not different between the groups.

\section{Paper III}

This paper presents results of exercise testing and quality of life assessment. There was a significantly greater improvement in exercise time in the $\mathrm{mBMC}$ group than in the control group $(2.1 \pm 1.9 \mathrm{~min}$ in the $\mathrm{mBMC}$ group compared with $1.2 \pm 1.3 \mathrm{~min}$ in the control group $(\mathrm{P}<0.01))$. Peak heart rate improved with $18.5 \pm 16.3$ beats $/ \mathrm{min}$ in the mBMC group compared with $13.3 \pm 15.8$ beats $/ \min (\mathrm{P}<0.05)$. However, the improvement in peak VO2 was not different between the groups $(2.8 \pm 3.9 \mathrm{ml} / \mathrm{kg} / \mathrm{min}$ in the $\mathrm{mBMC}$ 
group compared with $2.4 \pm 3.5 \mathrm{ml} / \mathrm{kg} / \mathrm{min}$ in the control group, $\mathrm{P}=0.62)$, and the improvement in exercise time in the $\mathrm{mBMC}$ group compared with the control group is probably a placebo effect. There were no differences between groups for quality of life assessed by the SF-36 health survey, neither at baseline nor for the change from 2-3 weeks to 6 months. The physical component summary (PCS) score improved significantly in both groups, whereas the mental component summary (MCS) score was mainly unchanged. At 6 months, both the PCS scores and the MCS scores were approximately at the same level as the general Norwegian population.

\section{Paper IV}

This paper summarizes changes in LV function over time, clinical outcome and safety during 12 months follow-up. Results obtained by echocardiography at baseline and at 3,6 and 12 months are presented, and there were no differences between groups for the changes in LVEF, WMSI or LVEDV. There was a similar improvement in LVEF and WMSI in both groups at 3 months followed by a stable state. For the entire patient population, LVEDV significantly increased at 6 months, but was unchanged compared to baseline at 3 and 12 months. The numbers of adverse events were similar in both groups, and all patients were alive after 12 months follow-up. 


\section{DISCUSSION}

In the randomized, but open-labeled ASTAMI study, intracoronary injection of autologous mBMC 4-8 days after anterior AMI did not improve LV function, quality of life, or infarct size. There was no difference between groups for the change in peak VO2, and the significantly greater increase in exercise time in the mBMC group than in the control group was regarded to be a placebo-effect. We did not find a dose-response effect for the number of mBMC (or CD34+ cells, unpublished data). Our results indicate that mBMC treatment is safe, since all patients were alive after 12 months, and the numbers of adverse events were generally low and similar in the groups.

Why were we unable to demonstrate a positive impact of cell therapy?

\section{Methodological considerations}

General

A phase III study to assess the effect of an intervention on the ultimate end point allcause mortality is usually regarded the gold-standard for cardiovascular trials. However, even though ischemic heart disease is a major cause of death world-wide and the major cause of congestive heart failure ${ }^{45}$, mortality rates are currently low in AMI patients treated with acute PCI. At RUH, 30 days mortality for all patients admitted with STEMI is $5.5 \%{ }^{46}$. In clinical trials, high risk patients with e.g. advanced age or cardiogenic shock are typically not included, and mortality rates are low. Thus, thousands of patients would 
have to be included to identify increased survival by any intervention. At the level of knowledge in this field at the time when the ASTAMI study was initiated, a phase III study would have been unethical. Therefore, the ASTAMI study was a phase II study. That means that in addition to confirming that intracoronary injection of autologous mBMC in patients with AMI was safe and feasible, the ASTAMI study was designed to evaluate the efficacy of this therapy. Treatment effect in a phase II trial is usually assessed with intermediate end points like measures of function and quality of life, or by a surrogate end point. The FDA defines a surrogate end point as a laboratory measurement or physical sign that is used in therapeutic trials as a substitute for a clinically meaningful end point that is a direct measure of how a patient feels, functions, or survives and is expected to predict the effect of the therapy. Especially patients with large, transmural infarcts are at particular risk of remodeling and the subsequent development of congestive heart failure (CHF) which again is associated with reduced survival $^{5,6}$. Therefore, improvement of LV function after AMI, which was the primary aim of the ASTAMI study, is a clinically relevant problem. Since BMC therapy was shown to regenerate myocardium and improve myocardial function in experimental models of AMI, attempts to improve LV function by BMC therapy in STEMI patients made intuitive sense and therefore has "face validity".

Variables of LV function that have been shown to predict outcome after AMI include $\mathrm{LVEF}^{47,48}, \mathrm{WMSI}^{48}, \mathrm{LV}$ volumes ${ }^{49}$, infarct size ${ }^{50}$ and echocardiographic measures of diastolic function like the ratio of $\mathrm{E} / \mathrm{Ea}^{51}$. $\mathrm{LVEF}$ is a measure of $\mathrm{LV}$ global function, and as all end points, LVEF has limitations. LVEF is often well preserved after AMI because 
of hyper-contractility of non-infarcted segments ${ }^{52}$, and may not be sensitive to detect changes in LV function. Furthermore, improvement in LVEF by an intervention does not necessarily translate to improved outcome ${ }^{53}$. However, LVEF is probably the best validated surrogate end point in cardiovascular trials. Improvement in LVEF and improved survival in patients with AMI has been shown for acute $\mathrm{PCI}^{54,55}, \mathrm{ACE}$ inhibitors $^{56,57}$ and beta-blockers ${ }^{58,59}$. Importantly, the degree of improvement in LVEF after vasodilator therapy (including ACE-inhibitors) predicted the clinical benefit ${ }^{60}$, indicating a close connection between the surrogate and the clinical outcome. Therefore, the choice of LVEF as the primary end point in the ASTAMI study is probably an adequate measure of improved LV function and therefore has "construct validity".

\section{Internal validity}

A study should be able to measure what it sets out to measure, i.e. it should have high internal validity. Bias may be defined as "deviation from truth", and bias reduces the internal validity of a study. There are several forms of bias in research

\section{Selection bias}

This means that there is a systematic difference between the study groups. The aim of the randomization procedure is to avoid selection bias. In the ASTAMI study, selection bias was probably not widespread since we did not find any differences between groups at baseline, and no patients were lost to follow-up ${ }^{43}$. 
Information bias

This means that there is a systematic difference between groups for collection of information. The ASTAMI study had potential for significant information bias since it was open-labeled (no sham procedures), and patients and some of the investigators were aware of treatment allocation. In other studies, the sham procedure has consisted of bone marrow aspiration and intracoronary injection of varying placebo mediums ${ }^{61,62}$. These procedures are however not indifferent since both bone marrow aspiration ${ }^{63}$ and $\mathrm{PCI}^{64}$ can induce an inflammatory response, and repeated balloon inflations in the infarct related coronary artery can affect the infarct process ${ }^{65}$. Therefore, a sham procedure may in fact increase the possibility for information bias when comparing intracoronary BMC treatment to standard optimal therapy in AMI patients. To reduce the risk of information bias in the ASTAMI study, all analyses on laboratory measures like LV function and QCA were performed in a blinded fashion. The collection of data on quality of life and some variables of exercise capacity were subject to information bias (placebo effect) which would be believed to favor the treatment group. This is probably the explanation for the discrepancy on exercise capacity results, since patient motivation has greater impact on exercise time than peak VO2. Of the 50 patients randomized to cell therapy, 3 patients did not receive mBMC treatment. Possible selection bias was avoided by the consistent use of the intention to treat strategy. This may have diluted a possible treatment effect of mBMC therapy, but this is probably not the case since exclusion of these 3 patients in the analyses did not influence results to a significant degree (unpublished data). 
Repeatability and effect measure

The validity of results depend on the repeatability of the effect measure. The greatest variability in assessment of LV function is usually caused by interrecording, followed by interobserver and then intraobserver variability ${ }^{66}$. Since the same investigator analyzed recordings for the same patient by SPECT and echocardiography, intraobserver and not interobserver variability was assessed. By MRI, interobserver variability is reported because this is of greater importance than intraobserver since different investigators analyzed recordings for the same patient. Re-read variability for LVEF by SPECT was $-1.0 \pm 3.7 \%$, and well within the estimated variation which was used for calculation of sample size ( $\mathrm{SD}=8.3 \%)$. Variability was at the same level by echo, better by trueFISP MRI and worse when FLASH MRI was used. For practical reasons, we did not assess interrecording variability. However, De Winter et al examined 20 patients with coronary artery disease and LVEF below $40 \%{ }^{67}$, and found day-to-day variability for LVEF by SPECT to be only $0.85 \pm 3.0 \%$. Interrecording repeatability for SPECT (and the other imaging modalities) in ASTAMI was likely below this level. However, precision was probably well within the value used in the power calculations.

Ideally, methods to assess the effect measure should also be accurate (reflect the truth). In ASTAMI, 3 inherent imaging techniques were used to measure LV function. Different values for LV volumes and infarct size were obtained with the different techniques, and this relates to methodological differences. At present, MRI with multiple short-axis recordings is regarded the gold standard for assessment of LV volumes. The $2 \mathrm{D}$ methods which were used to obtain LV volumes both for MRI and for echocardiography in 
ASTAMI are based on theoretical assumptions on LV shape. Especially in AMI patients with regional wall motion abnormalities this may not be correct. Furthermore, repeatability for FLASH MRI which was used in the majority of patients was suboptimal, and a method with high variability is by definition not precise and is unlikely to be accurate $^{68}$. The 3D approach which was used by SPECT is probably preferential, but it is unknown which method that best resembles true LV volumes (accuracy). However, the aim of the ASTAMI study was to assess differences between groups, not the absolute values per se.

To conclude, results on the effect measure in ASTAMI were consistent, since none of the 3 different imaging modalities revealed differences between groups for the change in LVEF, WMSI, LVEDV nor infarct size. This was also the case for quality of life data as well as exercise testing results, since objective measures like peak VO2, the anaerobic threshold (AT), time to AT, heart rate recovery, the VE/VCO2 slope and the oxygen uptake efficiency slope were also similar in the groups. This agreement is undoubtedly a strength of the ASTAMI study.

\section{Statistical bias}

This means the use of inappropriate statistical methods. In the ASTAMI study, analysis of covariance (ANCOVA) was used to assess end points with baseline and follow-up measurements (Paper II, III and IV). ANCOVA adjusts for possible baseline differences and is regarded more powerful than alternative methods like t-tests of follow-up or 
change scores ${ }^{69}$. The general linear regression model used for repeated measures also adjusted for possible baseline differences (Paper IV) ${ }^{70}$. The main statistical limitation of the ASTAMI study is the relatively low power of $80 \%$. This means that the probability of a type II error, i.e. that we did not detect a significant treatment effect when this was actually the case, was $20 \%$. Another aspect is that a difference between groups of $5 \%$ for $\triangle$ LVEF was considered a clinically important treatment effect of mBMC therapy. Even though this estimate is supported by data from the V-HeFT trials ${ }^{60}$, it is not known whether this is relevant for cell therapy, and less pronounced differences may potentially also be of importance. More patients would have to be included to detect a less pronounced treatment effect and/or to reduce the risk of a type II error.

\section{External validity}

During the inclusion period, we screened 1608 STEMI patients admitted for acute PCI for inclusion in the ASTAMI study ${ }^{43}$, and only $100(6.2 \%)$ were included in the analysis. To what degree can results of the ASTAMI study be extended to the general AMI population? Acute PCI is currently the standard revascularization strategy for AMI patients in Norway, and even though the use of medical therapy in the ASTAMI study was extensive, this is also the case after AMI in the general Norwegian population ${ }^{71}$. Table 1 shows differences between included and non-included patients for some variables that were collected during inclusion. Data are complete for RUH, but partially missing for UUH. 


\section{Table 1}

Characteristics of included versus non-included patients

\begin{tabular}{lccc} 
& Included & Non-included & P value \\
\hline Age & $\begin{array}{c}57.4 \pm 9.1 \\
\mathrm{n}=100\end{array}$ & $\begin{array}{c}62.4 \pm 13.0 \\
\mathrm{n}=1502\end{array}$ & $<0.001$ \\
$\begin{array}{l}16(16 \%) \\
\mathrm{n}=100\end{array}$ & $\begin{array}{c}360(24 \%) \\
\mathrm{n}=1503\end{array}$ & 0.06 \\
Female sex & $\begin{array}{c}06(96 \%) \\
\mathrm{n}=100\end{array}$ & $\begin{array}{c}1421(95 \%) \\
\mathrm{n}=1500\end{array}$ & 0.83 \\
Caucasian etnicity & $324(190$ to 400$)$ & $225(87$ to 400$)$ & $<0.01$ \\
& $\mathrm{n}=60$ & $\mathrm{n}=678$ & \\
$\begin{array}{l}\text { Maximum CK-MB } \\
(\mu \mathrm{g} / \mathrm{L})\end{array}$ & $210(180$ to 330$)$ & $240(170$ to 420$)$ & 0.21 \\
$\begin{array}{l}\text { Time from symptom } \\
\text { onset to PCI }\end{array}$ & $\mathrm{n}=85$ & $\mathrm{n}=1170$ &
\end{tabular}

Data are mean $\pm \mathrm{SD}$, number (proportion) or median (interquartile range). $\mathrm{P}$ values were obtained by the independent t-test, the chi-square test or the Mann-Whitney test as appropriate. For CK-MB, only data from RUH are presented since no data for non-included patients were available from UUH.

Included patients were younger than non-included, and there was a strong trend for less women among included patients. When comparing only patients within the age inclusion criteria in ASTAMI (40 to 75 years), the age of non-included patients was $58.9 \pm 9.3$ years $(\mathrm{P}=0.14$ compared with included patients), and there were $224(19 \%)$ females in the non-included group $(\mathrm{P}=0.39)$. Included patients had higher values for $\mathrm{CK}-\mathrm{MB}$, indicating that the inclusion criteria succeeded in selecting patients with large infarcts, where a positive treatment effect would have the greatest impact. The results of the ASTAMI study are therefore probably valid for patients of age $40-75$ years with large infarcts. 


\section{Comparison with other studies}

Since the BMC subpopulation that may be responsible cardiac regeneration has not yet been identified, unfractioned BMC were used in the ASTAMI study and in several other trials. Results of the ASTAMI study have been said to be in conflict with similar studies, especially in relation to results of the REPAIR-AMI study ${ }^{62}$. In the REPAIR-AMI study, 204 AMI patients reperfused with acute PCI were randomized to intracoronary injection of $\mathrm{mBMC}$ or placebo. The primary end point was the change in LVEF measured by single-plane angiocardiography. After 4 months follow-up, LVEF increased with $5.5 \pm 7.3 \%$ in the $\mathrm{mBMC}$ group compared to $3.0 \pm 6.5 \%$ in the placebo group $(\mathrm{p}=0.01)$, i.e. an absolute treatment effect of $2.5 \%$ points. It has been suggested that different protocols for preparation of the bone marrow account for the different results, since mBMC prepared according to the ASTAMI protocol were found to have impaired functional capacity $^{72}$. Especially the use of autologous heparin-plasma for overnight mBMC storage was found to reduce migratory capacity against SDF-1 in vitro, and neovascularisation capacity in a hind-limb ischemia model in mice, when compared to results obtained after storage in the cell culture medium X VIVO 10 (Cambrex Bio Science, Walkersville, MD, USA). Unfortunately, these experiments were performed by the REPAIR-AMI investigators only, based on an incomplete brief protocol version. It is therefore unknown whether the exact cell preparation conditions in the ASTAMI study were actually reproduced. Cell preparation in the ASTAMI study was based on methods that are proven to be successful for patients with hematological diseases ${ }^{40}$. Whether or not these results can be transferred to the clinical scenario of cardiac repair by BMC remains unknown. 
Some preclinical data indicate that for reconstitution of the bone marrow, single cell grafting may be sufficient ${ }^{29}$, and mechanisms for homing and engraftment of BMC may be different in different organs. As discussed in the methods section, the cell culture medium RPMI-1640 was intended for cell storage in the original protocol, but for safety concerns, the use was restricted by the NoMA. In this respect, it is noteworthy that the manufacturer of X VIVO 10 is unaware of safety data for intracoronary administration of this substance ${ }^{73}$. The possibility that the use of RPMI-1640 would have changed the results of the ASTAMI study remains speculative. Instead, the simple fact that the ASTAMI study was not powered to detect a treatment effect of the change in LVEF of less than $5 \%$, and the use of a suboptimal method for assessment of LV function in REPAIR-AMI ${ }^{73}$ may account for the different results. Table 2 summarizes results of larger randomized clinical trials with BMC therapy in patients with AMI. The change in LVEF was the primary end-point in most of these studies. In the BOOST trial, only a temporary treatment effect on LVEF was found ${ }^{74,75}$, and results of the study by Janssens et al indicated reduced infarct size and improved regional function, but no effect on $\mathrm{LVEF}^{61}$. In a study with only 20 patients in each group, Meluzin et al found a small effect of $100 \times 10^{6} \mathrm{mBMC}$ compared to $10 \times 10^{6}$ or control $^{76}$, and in the rather small TCT-STAMI study, mBMC therapy improved LVEF compared to a control group where no improvement in LVEF was observed ${ }^{77}$. To conclude, the effect of BMC therapy in larger randomized clinical trials has at best been found moderate, and are therefore not in true conflict with results of the ASTAMI study. 


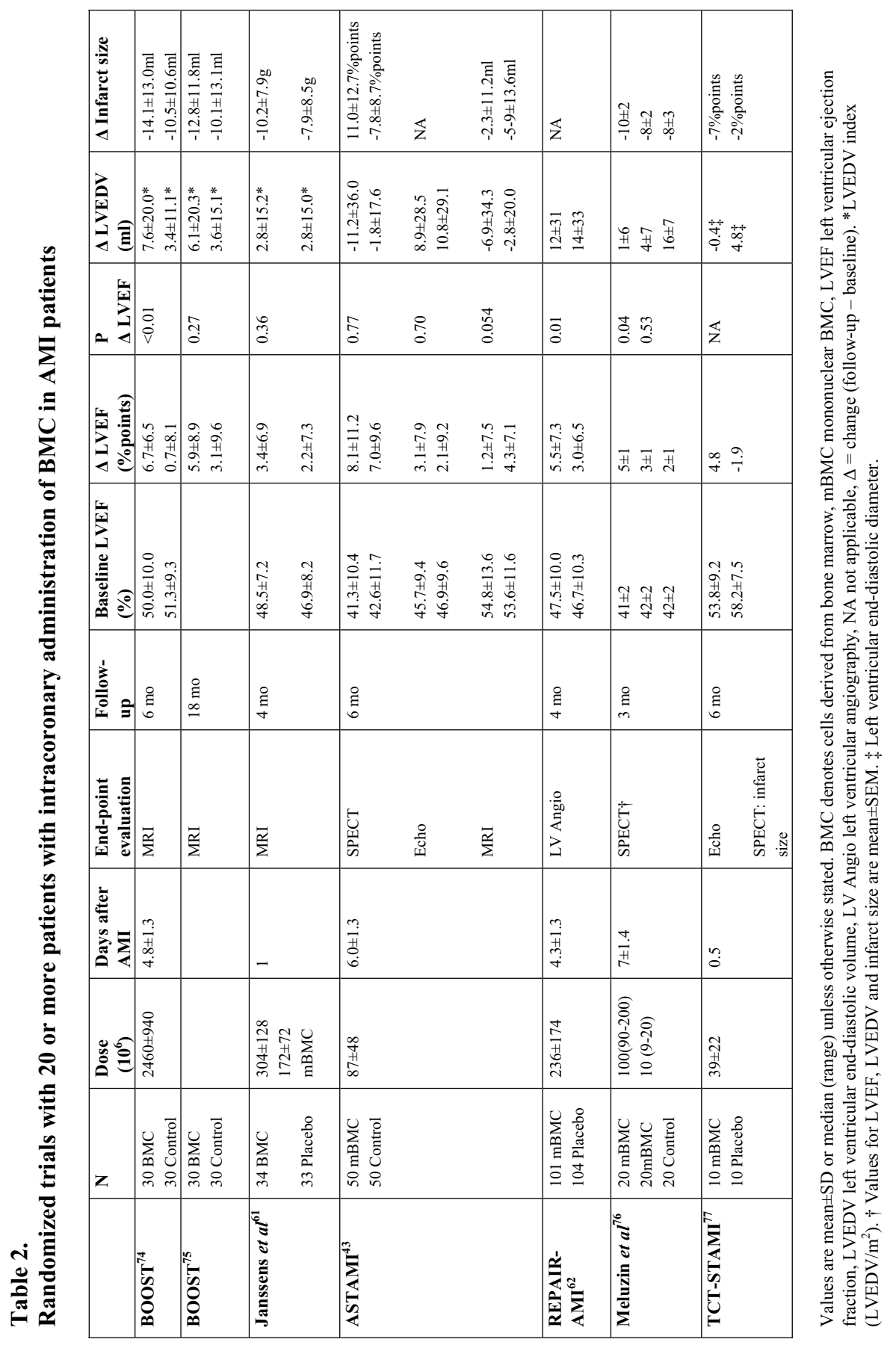




\section{General aspects}

The concept of intracoronary injection of BMC for improvement of LV function in patients with AMI has several limitations which may explain why we did not find a treatment effect in the ASTAMI study.

\section{Transdifferentiation}

Several groups could not reproduce transdifferentiation of BMC, and fusion of transplanted cells with host-cells may have accounted for the observations that were interpreted as transdifferentiation ${ }^{78,79}$. Another possible explanations for the discrepancy include different techniques for detection of transplanted cells ${ }^{80}$. Orlic et al at the Valhalla institute injected BMC tagged with green fluorescent protein, and trusted the identification of fluorescent cardiomyocytes as an indication of transdifferention of BMC to cardiomyocytes ${ }^{22}$. These findings may however have been mixed with cardiomyocyte autofluorescence artefacts ${ }^{81}$. When more sophisticated genetic markers were used, either little activity of the reporter was observed ${ }^{82}$, or BMC were shown to differentiate to mature blood cells when placed in ischemic myocardium ${ }^{83}$. Recently, in a cooperation with three other laboratories, the researchers at the Valhalla institute provided repeated evidence that BMC actually can transdifferentiate and regenerate myocardium ${ }^{84}$. Unfortunately, none of the laboratories behind the negative transdifferentiation reports participated in the new studies. Whether significant myocardial regeneration by transdifferentiation of BMC is possible or not remains unsettled. 
The initial findings of large amounts ( $9 \%$ with $50 \%$ sensitivity, indicating a total of $18 \%$ ) of recipient derived cardiomyocytes in sex-mismatched heart transplantation ${ }^{32}$ have also been challenged. Other investigators found only $0.02-0.04 \%$ cardiomyocytes with recipient origin in the transplanted hearts ${ }^{85,86}$. Thus, the biological significance of possible cardiac repair by $\mathrm{BMC}$ as a naturally occurring phenomenon has been questioned.

Even though the original concept of transdifferentiation to cardiomyocytes is heavily disputed, BMC have improved myocardial function in most studies after experimental myocardial infarction. However, similar results have been obtained by transplantation of numerous cell types including skeletal myoblasts ${ }^{87}$, smooth muscle cells $^{88}$, and fibroblasts ${ }^{89}$. Thus, it seems like every cell type exert a positive effect after intramyocardial injection ${ }^{90}$. This may in part be explained by improved passive mechanical properties of the myocardium purely after injection of material like cellular masses $^{91}$. Furthermore, since it is unlikely that so many cell types have potential for transdifferentiation to cardiomyocytes, other explanations for possible mechanism have been suggested. The concept that bone-marrow derived EPC contribute to formation of new blood vessels (angiogenesis) is less controversial ${ }^{92}$. Indeed, in an early report in 2001, Kocher et al found that transplanted human EPC indirectly reduced cardiomyocyte apoptosis after experimental AMI in mice through angiogenesis ${ }^{37}$. Thus, improved perfusion may be the mechanism behind the improvement in LV function that have been observed after mBMC treatment ${ }^{62}$, and a phase I study with EPC for treatment of patients 
with severe angina pectoris and no further revascularization options have yielded positive results ${ }^{93}$.

Other mechanisms

BMC secrete growth factors and cytokines that are known to exert angiogenic effects, and may stimulate endogenous cardiac repair by paracrine action rather than transdifferentiation to cardiac cells ${ }^{94}$. For example, similar reduction of infarct size and improvement of myocardial function was found either MSC or only the cell-free conditioned media was injected after experimental $\mathrm{AMI}^{95}$. Immune modulation is another suggested mechanism ${ }^{96}$, and indeed, mBMC therapy may have resulted in a slightly reduced long-term inflammatory response in the ASTAMI study ${ }^{97}$. However, cell therapy strategies that may work in otherwise young and healthy laboratory animals, may not have the same potential in a clinical setting with older patients with multiple risk factors, where both cell functionality and the biological responses to cell therapy are likely to be impaired $^{98}$.

Dose

The left ventricle contains approximately $4-5 \times 10^{9}$ cardiomyocytes $^{90,99}$. In the ASTAMI study, the mean infarct size at 6 months was approximately $20 \%$ by MRI and $30 \%$ by SPECT. Thus, at least $1 \times 10^{9}$ cardiomyocytes should ideally be replaced. The median number of mBMC injected in the ASTAMI study was $68 \times 10^{6}$, the median number of CD34+ progenitor cells was $0.7 \times 10^{6}$, and the number of MSC and multipotent HSC was even smaller since these cells are scarce within the bone marrow. Furthermore, only a 
few $\%$ of the cells remain in the heart after intracoronary injection ${ }^{100,101}$, and a large proportion die within a few days ${ }^{102}$. Accordingly, the number of cells that were delivered were out of proportion compared to the need. Cell numbers in the ASTAMI study was higher than in the study by Strauer et $\mathrm{al}^{38}$ and the TCT-STAMI study ${ }^{77}$, similar to the study by Fernandez-Aviles et $a l^{103}$ and the high dose group in the study by Meluzin et $a l^{76}$, and less than in the BOOST study ${ }^{74}$, the study by Janssens $e t a l^{61}$ and the REPAIRAMI study ${ }^{62}$. However, a large discrepancy between the number of cardiomyocytes that need to be regenerated after an AMI and the number of stem and progenitor cells that have been transplanted to the heart is a common feature of all the studies that have been performed. Relative to the size of the heart, more cells were transplanted in the studies in mice. Assuming mouse and human BMC to be equally efficacious, and considering transdifferentiation possible, it has been calculated that at best $1-5 \mathrm{~g}$ myocardium could be regenerated in the human trials with the number of transplanted cells ${ }^{104}$. Another issue questioning the concept is the lack of a dose-response relationship in the clinical studies. In the TOPCARE-AMI ${ }^{105}$, the BOOST study ${ }^{74}$, and the ASTAMI study ${ }^{43}$, no significant correlation between improvement in LV function and the total number of BMC or CD34+ cells was found. This may however be related to underdosing in all the studies. If regeneration of myocardium was limited to $5 \mathrm{~g}$, it is unlikely that any available method for assessment of LV function could have detected a treatment effeect ${ }^{104}$.

\section{Cell delivery}

Intracoronary injection of $\mathrm{BMC}$ is a relatively simple and feasible technique for delivery of cells to the human heart. The technique was first described by Strauer et al, and it was 
based on the assumption that BMC would be attracted by cytokines and signalling molecules, adhere to the endothelium at the sites of myocardial necrosis by expression of specific receptors, extravasate and engraft in niches in the myocardium (homing) ${ }^{38}$. By this method, cells are delivered to perfused areas of the myocardium, reducing the risk of ischemic cell death. Studies have however shown that 1-2 hours after administration of cells, only $1-5 \%$ of radiolabeled BMC remain in the heart by this method ${ }^{100,101}$. Hofmann et al showed superior retention of CD34+ progenitor cells $(14-39 \%$ remained in the heart 60-75 min after intracoronary injection) ${ }^{100}$. This was however not confirmed by Blocklet et al, who found only $5.5 \%$ of CD34+ cells within the myocardium 1 hour after injection ${ }^{106}$. Therefore, it seems obligate to improve methods for cell delivery to obtain a treatment effect. However, cell engraftment by alternative methods for cell delivery is also disappointing. In a porcine model of AMI, Hou et al tested the efficacy of intracoronary, retrograde coronary venous injection and direct intramyocardial injections of peripheral blood mononuclear cells ${ }^{107}$. One hour after cell delivery, $11 \%$ of the cells remained in the heart after intramyocardial injections, whereas only approximately $3 \%$ of the cells remained in the heart by the other methods. Therefore, further research to increase engraftment of transplanted cells within the myocardium seems mandatory to improve results after cell therapy, irrespective of whether transdifferentiation, paracrine effects or immune-modulation are involved.

\section{Timing of treatment}

Strauer et al estimated the ideal timing for cell delivery to be between 7 and 14 days after the AMI, based on the assumption that earlier treatment would expose the cells to a 
hostile, inflammatory environment, and that effects of later treatment would be hampered by scar formation within the myocardium ${ }^{38}$. In the TOPCARE-AMI study, cells were delivered $4 \pm 1.5$ days after the $\mathrm{AMI}^{39}$. In the ASTAMI study, timing of treatment to day 4-8 after the AMI was also based on assumptions of a trade-off between the early inflammatory response, and the subsequent scar development. Results of the REPAIRAMI study showed that the improvement in LV function was confined to the patients which were treated $\geq 5$ days after the $\mathrm{AMI}^{62}$. However, we did not observe any treatment effect even though cells were injected at a median of 6 days after the $\mathrm{AMI}^{43}$. In a small study, beneficial effects of intracoronary $\mathrm{mBMC}$ injections were found when cells were injected in the hyperacute phase of the AMI, i.e. a mean time of 3 hours after $\mathrm{PCI}^{77}$. Few experimental studies have assessed the effect of timing on engraftment and efficacy of cell therapy ${ }^{108}$. However, neither timing nor cell type (MSC or mBMC) affected engraftment after intramyocardial injections in experimental infarction in rats ${ }^{109}$. Currently, the ideal timing for cell delivery after AMI is unknown.

\section{PERSPECTIVES}

Cell therapy for heart disease is in its infancy. Further research is needed to identify the optimal cell type and dose, improve cell delivery techniques and to determine the optimal timing for cell treatment. Specific BMC subpopulations may be preferential compared to unfractioned $\mathrm{BMC}$, and Chen et al reported a large treatment effect of intracoronary injection of $\mathrm{MSC}^{110}$, but these results need to be confirmed in other studies. The safety of MSC have been questioned, since intracoronary injection of such cells caused 
microinfarction in $\operatorname{dog} \mathrm{s}^{111}$, and recently, myocardial ossification was observed after intramyocardial injections of MSC in mice ${ }^{112}$. EPC seem to be a reasonable cell type for therapeutic angiogenesis, and results of phase II studies with intramyocardial injections of such cells in patients with angina pectoris and no further revascularisation opportunities are awaited. Mobilisation of BMC with the cytokine granulocyte colonystimulating factor (G-CSF) has been tested clinically as an alternative to the direct cardiac administration of BMC. Data from clinical trials indicate that administration of G-CSF presently has no role for treatment of patients with ischemic heart disease $\mathrm{e}^{113}$. Intramyocardial injection of skeletal myoblasts has been tested in patients with established myocardial scars. These cells are however committed to become skeletal myocytes and do not integrate with the myocardium since they do not express gap junction proteins. In the largest study testing this approach to date, results were rather disappointing $^{114}$.

Without doubt, ESC have potential for differentiation to all cell types needed for myocardial regeneration. The use of ESC is however hampered by several concerns. The ethical aspect is controversial, the rate of spontaneous cardiomyocyte differentiation of ESC is low and cell survival is poor after transplantation of undifferentiated $\mathrm{ESC}^{115}$ or unmanipulated human ESC derived cardiomycytes ${ }^{116}$ to the heart. The pluripotency of these cells is also a safety concern, since teratomas were observed after intramyocardial injection of undifferentiated $\operatorname{ESC}^{115,117}$. Several of these hurdles may be overcome, and techniques for increased cardiomyocyte differentiation and survival of human ESC after transplantation to infarcted rat hearts have been described ${ }^{115,116}$. Some researchers believe ESC are immune privileged, since they express low levels of major 
histocompatibility complex (MHC) molecules and insignificant recognition by natural killer receptors ${ }^{118}$. However, exposure to inflammation (interferon- $\gamma$ ) increased expression of MHC molecules ${ }^{118}$, and after intramyocardial injection of ESC in infarcted baboon hearts, all transplanted cells were rejected ${ }^{119}$. Somatic cell nuclear transfer was suggested as a novel technique to produce immune privileged human ESC, but this opportunity remains hypothetical since these reports were found to be manipulated ${ }^{120}$. ESC transplantation appears less attractive if close MHC matching and immunosuppresion is needed to avoid rejection of transplanted cells. Recently, the findings that human skin fibroblasts can be genetically modified to obtain pluripotent stem cells ${ }^{121,122}$ has created great expectations for the future of regenerative medicine. It is however currently unknown whether such cells can be used to regenerate the heart.

\section{CONCLUSION}

In the ASTAMI study, we did not find any clinically significant effects of intracoronary injection of autologous $\mathrm{mBMC}$ in patients with AMI. The lack of a treatment effect may be a type II error, and possibly, alternative methods for preparing mBMC may have changed results. However, our results are not in true conflict with results of other, similar studies. The restricted clinical success is probably related to conceptual limitations like insufficient cell numbers permanently engrafted in the myocardium, and the questionable capacity for transdifferentiation of BMC to cardiomyocytes. Further research is needed before cell treatment can be recommended for patients with AMI. 


\section{REFERENCE LIST}

1. Callow AD. Cardiovascular disease 2005 - the global picture. Vascular Pharmacology 2006;45:302-7.

2. Antman EM, Anbe DT, Armstrong PW et al. ACC/AHA Guidelines for the management of patients with ST-elevation myocardial infarction. Circulation 2004;110:e82-e292.

3. Giugliano RP, Braunwald E. Selecting the best reperfusion strategy in STelevation myocardial infarction: It's all a matter of time. Circulation 2003;108:2828-30.

4. Thygesen K, Alpert JS, White HD et al. Universal definition of myocardial infarction. Circulation 2007;116:2634-53.

5. Pfeffer MA, Braunwald E. Ventricular remodeling after myocardial infarction. Experimental observations and clinical implications. Circulation 1990;81:116172.

6. Braunwald E, Pfeffer MA. Ventricular enlargement and remodeling following acute myocardial infarction: mechanisms and management. Am J Cardiol 1991;68:1D-6D.

7. Rosamond W, Flegal K, Friday G et al. Heart disease and stroke statistics--2007 update: A report from the American Heart Association Statistics Committee and Stroke Statistics Subcommittee. Circulation 2007;115:e69-171.

8. Engel FB. Cardiomyocyte proliferation: a platform for mammalian cardiac repair. Cell Cycle 2005;4:1360-3.

9. Pollack M, Phaneuf S, Dirks A, Leeuwenburgh C. The role of apoptosis in the normal aging brain, skeletal muscle, and heart. Ann N Y Acad Sci 2002;959:93107.

10. Nadal-Ginard B, Kajstura J, Leri A, Anversa P. Myocyte death, growth, and regeneration in cardiac hypertrophy and failure. Circ Res 2003;92:139-50.

11. Ellison GM, Torella D, Karakikes I, Nadal-Ginard B. Myocyte death and renewal: modern concepts of cardiac cellular homeostasis. Nat Clin Pract Cardiovasc Med 2007;4 Suppl 1:S52-S59.

12. Dimmeler S, Burchfield J, Zeiher AM. Cell-based therapy of myocardial infarction. Arterioscler Thromb Vasc Biol 2008;28:208-16. 
13. Kajstura J, Leri A, Finato N, Di Loreto C, Beltrami CA, Anversa P. Myocyte proliferation in end-stage cardiac failure in humans. Proc Natl Acad Sci U S A 1998;95:8801-5.

14. Urbanek K, Quaini F, Tasca G et al. Intense myocyte formation from cardiac stem cells in human cardiac hypertrophy. Proc Natl Acad Sci U S A 2003;100:10440-5.

15. Beltrami AP, Urbanek K, Kajstura J et al. Evidence that human cardiac myocytes divide after myocardial infarction. N Engl J Med 2001;344:1750-7.

16. Mouquet $\mathrm{F}$, Pfister $\mathrm{O}$, Jain $\mathrm{M}$ et al. Restoration of cardiac progenitor cells after myocardial infarction by self-proliferation and selective homing of bone marrowderived stem cells. Circ Res 2005;97:1090-2.

17. Fazel S, Cimini M, Chen L et al. Cardioprotective c-kit+ cells are from the bone marrow and regulate the myocardial balance of angiogenic cytokines. J Clin Invest 2006;116:1865-77.

18. Appelbaum FR. Hematopoietic-cell transplantation at 50. N Engl J Med 2007;357:1472-5.

19. Brazelton TR, Rossi FM, Keshet GI, Blau HM. From marrow to brain: expression of neuronal phenotypes in adult mice. Science 2000;290:1775-9.

20. Theise ND, Nimmakayalu M, Gardner R et al. Liver from bone marrow in humans. Hepatology 2000;32:11-6.

21. Ferrari G, Cusella-De Angelis G, Coletta $\mathrm{M}$ et al. Muscle regeneration by bone marrow-derived myogenic progenitors. Science 1998;279:1528-30.

22. Orlic D, Kajstura J, Chimenti S et al. Bone marrow cells regenerate infarcted myocardium. Nature 2001;410:701-5.

23. Jackson KA, Majka SM, Wang H et al. Regeneration of ischemic cardiac muscle and vascular endothelium by adult stem cells. J Clin Invest 2001;107:1395-402.

24. Jiang Y, Jahagirdar BN, Reinhardt RL et al. Pluripotency of mesenchymal stem cells derived from adult marrow. Nature 2002;418:41-9.

25. Choi K, Kennedy M, Kazarov A, Papadimitriou JC, Keller G. A common precursor for hematopoietic and endothelial cells. Development 1998;125:725-32.

26. Horwitz EM, Le BK, Dominici M et al. Clarification of the nomenclature for MSC: The International Society for Cellular Therapy position statement. Cytotherapy 2005;7:393-5.

27. Wognum AW, Eaves AC, Thomas TE. Identification and isolation of hematopoietic stem cells. Arch Med Res 2003;34:461-75. 
28. Leor J, Marber M. Endothelial progenitors: a new Tower of Babel? J Am Coll Cardiol 2006;48:1588-90.

29. Matsuzaki Y, Kinjo K, Mulligan RC, Okano H. Unexpectedly efficient homing capacity of purified murine hematopoietic stem cells. Immunity 2004;20:87-93.

30. Alison MR, Poulsom R, Forbes S, Wright NA. An introduction to stem cells. J Pathol 2002;197:419-23.

31. Pittenger MF, Martin BJ, Finkel T, Bolli RE. Mesenchymal stem cells and their potential as cardiac therapeutics. Circ Res 2004;95:9-20.

32. Quaini F, Urbanek K, Beltrami AP et al. Chimerism of the transplanted heart. N Engl J Med 2002;346:5-15.

33. Bayes-Genis A, Salido M, Sole RF et al. Host cell-derived cardiomyocytes in sexmismatch cardiac allografts. Cardiovasc Res 2002;56:404-10.

34. Deb A, Wang S, Skelding KA, Miller D, Simper D, Caplice NM. Bone marrowderived cardiomyocytes are present in adult human heart: A study of gendermismatched bone marrow transplantation patients. Circulation 2003;107:1247-9.

35. Caplice NM, Bunch TJ, Stalboerger PG et al. Smooth muscle cells in human coronary atherosclerosis can originate from cells administered at marrow transplantation. Proc Natl Acad Sci U S A 2003;100:4754-9.

36. Mallory GK, White PD, Salcedo-Salgar J. The speed of healing of myocardial infarction: A study of the pathologic anatomy in 72 cases. Am Heart J 1939;18:647-71.

37. Kocher AA, Schuster MD, Szabolcs MJ et al. Neovascularization of ischemic myocardium by human bone-marrow-derived angioblasts prevents cardiomyocyte apoptosis, reduces remodeling and improves cardiac function. Nat Med 2001;7:430-6.

38. Strauer BE, Brehm M, Zeus T et al. Repair of infarcted myocardium by autologous intracoronary mononuclear bone marrow cell transplantation in humans. Circulation 2002;106:1913-8.

39. Assmus B, Schächinger V, Teupe $\mathrm{C}$ et al. Transplantation of progenitor cells and regeneration enhancement in acute myocardial infarction (TOPCARE-AMI). Circulation 2002;106:3009-17.

40. Egeland T, Brinchmann JE. Cell quality in the ASTAMI study. Eur Heart J 2007;28:2172.

41. Gibbons RJ, Valeti US, Araoz PA, Jaffe AS. The quantification of infarct size. J Am Coll Cardiol 2004;44:1533-42. 
42. Schulz-Menger J, Gross M, Messroghli D, Uhlich F, Dietz R, Friedrich MG. Cardiovascular magnetic resonance of acute myocardial infarction at a very early stage. J Am Coll Cardiol 2003;42:513-8.

43. Lunde K, Solheim S, Aakhus S et al. Intracoronary injection of mononuclear bone marrow cells in acute myocardial infarction. N Engl J Med 2006;355:1199-209.

44. Hansegard J, Urheim S, Lunde K, Rabben SI. Constrained active appearance models for segmentation of triplane echocardiograms. IEEE Trans Med Imaging 2007;26:1391-400.

45. Fox KF, Cowie MR, Wood DA et al. Coronary artery disease as the cause of incident heart failure in the population. Eur Heart J 2001;22:228-36.

46. Quality data for Department of Cardiology, Rikshospitalet University Hospital. Accessed on February 17, 2008. http://www.rikshospitalet.no/portal/page/portal/no/forsiden/klinikkene/content?p $\underline{\operatorname{dim} \mathrm{id}=43093 \text {. }}$

47. The multicenter postinfarction research group. Risk stratification and survival after myocardial infarction. N Engl J Med 1983;309:331-6.

48. Moller JE, Hillis GS, Oh JK, Reeder GS, Gersh BJ, Pellikka PA. Wall motion score index and ejection fraction for risk stratification after acute myocardial infarction. Am Heart J 2006;151:419-25.

49. White HD, Norris RM, Brown MA, Brandt PW, Whitlock RM, Wild CJ. Left ventricular end-systolic volume as the major determinant of survival after recovery from myocardial infarction. Circulation 1987;76:44-51.

50. Wu KC, Zerhouni EA, Judd RM et al. Prognostic significance of microvascular obstruction by magnetic resonance imaging in patients with acute myocardial infarction. Circulation 1998;97:765-72.

51. Hillis GS, Moller JE, Pellikka PA et al. Noninvasive estimation of left ventricular filling pressure by E/e' is a powerful predictor of survival after acute myocardial infarction. J Am Coll Cardiol 2004;43:360-7.

52. Kjoller E, Kober L, Jorgensen S, Torp-Pedersen C. Long-term prognostic importance of hyperkinesia following acute myocardial infarction. Am J Cardiol 1999;83:655-9.

53. Packer M, Carver JR, Rodeheffer RJ et al. Effect of oral milrinone on mortality in severe chronic heart failure. The PROMISE Study Research Group. N Engl J Med 1991;325:1468-75. 
54. Stone GW, Grines CL, Cox DA et al. Comparison of angioplasty with stenting, with or without Abciximab, in acute myocardial infarction. N Engl J Med 2002;346:957-66.

55. Keeley EC, Boura JA, Grines CL. Primary angioplasty versus intravenous thrombolytic therapy for acute myocardial infarction: a quantitative review of 23 randomised trials. Lancet 2003;361:13-20.

56. Pfeffer MA, Lamas GA, Vaughan DE, Parisi AF, Braunwald E. Effect of captopril on progressive ventricular dilatation after anterior myocardial infarction. N Engl J Med 1988;319:80-6.

57. Pfeffer MA, Braunwald E, Moye LA et al. Effect of captopril on mortality and morbidity in patients with left ventricular dysfunction after myocardial infarction. Results of the survival and ventricular enlargement trial. The SAVE Investigators. N Engl J Med 1992;327:669-77.

58. Dargie HJ. Effect of carvedilol on outcome after myocardial infarction in patients with left-ventricular dysfunction: the CAPRICORN randomised trial. Lancet 2001;357:1385-90.

59. Doughty RN, Whalley GA, Walsh HA, Gamble GD, Lopez-Sendon J, Sharpe N. Effects of carvedilol on left ventricular remodeling after acute myocardial infarction: the CAPRICORN Echo Substudy. Circulation 2004;109:201-6.

60. Cintron G, Johnson G, Francis G, Cobb F, Cohn JN. Prognostic significance of serial changes in left ventricular ejection fraction in patients with congestive heart failure. The V-HeFT VA Cooperative Studies Group. Circulation 1993;87:VI17VI23.

61. Janssens S, Dubois C, Bogaert J et al. Autologous bone marrow-derived stem-cell transfer in patients with ST-segment elevation myocardial infarction: doubleblind, randomised controlled trial. The Lancet 2006;367:113-21.

62. Schächinger V, Erbs S, Elsässer A et al. Intracoronary bone marrow-derived progenitor cells in acute myocardial infarction. N Engl J Med 2006;355:1210-21.

63. Cluitmans FH, Esendam BH, Veenhof WF, Landegent JE, Willemze R, Falkenburg JH. The role of cytokines and hematopoietic growth factors in the autocrine/paracrine regulation of inducible hematopoiesis. Ann Hematol 1997;75:27-31.

64. Paroli M, Mariani P, Accapezzato D et al. Modulation of tachykinin and cytokine release in patients with coronary disease undergoing percutaneous revascularization. Clin Immunol 2004;112:78-84.

65. Staat $\mathrm{P}$, Rioufol G, Piot $\mathrm{C}$ et al. Postconditioning the human heart. Circulation 2005;112:2143-8. 
66. Anand IS, Florea VG, Solomon SD, Konstam MA, Udelson JE. Noninvasive assessment of left ventricular remodeling: concepts, techniques, and implications for clinical trials. J Card Fail 2002;8:S452-S464.

67. De WO, De BP, Van De WC, De BG, Dierckx RA, De SJ. Day-to-day variability of global left ventricular functional and perfusional measurements by quantitative gated SPECT using Tc-99m tetrofosmin in patients with heart failure due to coronary artery disease. J Nucl Cardiol 2004;11:47-52.

68. Bland JM, Altman DG. Statistical methods for assessing agreement between two methods of clinical measurement. Lancet 1986;1:307-10.

69. Vickers AJ, Altman DG. Statistics Notes: Analysing controlled trials with baseline and follow up measurements. Br Med J 2001;323:1123-4.

70. Fitzmaurice GM. Applied longitudinal analysis. Hoboken, N.J.: WileyInterscience; 2004.

71. Reikvam A, Kvan E, Aursnes I. Use of cardiovascular drugs after acute myocardial infarction: a marked shift towards evidence-based drug therapy. Cardiovasc Drugs Ther 2002;16:451-6.

72. Seeger FH, Tonn T, Krzossok N, Zeiher AM, Dimmeler S. Cell isolation procedures matter: a comparison of different isolation protocols of bone marrow mononuclear cells used for cell therapy in patients with acute myocardial infarction. Eur Heart J 2007;28:766-72.

73. Arnesen H, Lunde K, Aakhus S, Forfang K. Cell therapy in myocardial infarction. Lancet 2007;369:2142-3.

74. Wollert KC, Meyer GP, Lotz J et al. Intracoronary autologous bone-marrow cell transfer after myocardial infarction: the BOOST randomised controlled clinical trial. Lancet 2004;364:141-8.

75. Meyer GP, Wollert KC, Lotz J et al. Intracoronary bone marrow cell transfer after myocardial infarction: Eighteen months' follow-up data from the randomized, controlled BOOST (BOne marrOw transfer to enhance ST-elevation infarct regeneration) trial. Circulation 2006;113:1287-94.

76. Meluzin J, Mayer J, Groch L et al. Autologous transplantation of mononuclear bone marrow cells in patients with acute myocardial infarction: the effect of the dose of transplanted cells on myocardial function. Am Heart J 2006;152:975-15.

77. Ge J, Li Y, Qian J et al. Efficacy of emergent transcatheter transplantation of stem cells for treatment of acute myocardial infarction (TCT-STAMI). Heart 2006;92:1764-7. 
78. Alvarez-Dolado M, Pardal R, Garcia-Verdugo JM et al. Fusion of bone-marrowderived cells with Purkinje neurons, cardiomyocytes and hepatocytes. Nature 2003;425:968-73.

79. Nygren JM, Jovinge S, Breitbach $\mathrm{M}$ et al. Bone marrow-derived hematopoietic cells generate cardiomyocytes at a low frequency through cell fusion, but not transdifferentiation. Nat Med 2004;10:494-501.

80. Chien KR. Stem cells: lost in translation. Nature 2004;428:607-8.

81. Laflamme MA, Murry CE. Regenerating the heart. Nat Biotech 2005;23:845-56.

82. Murry CE, Soonpaa MH, Reinecke $\mathrm{H}$ et al. Haematopoietic stem cells do not transdifferentiate into cardiac myocytes in myocardial infarcts. Nature 2004;428:664-8.

83. Balsam LB, Wagers AJ, Christensen JL, Kofidis T, Weissman IL, Robbins RC. Haematopoietic stem cells adopt mature haematopoietic fates in ischaemic myocardium. Nature 2004;428:668-73.

84. Rota M, Kajstura J, Hosoda T et al. Bone marrow cells adopt the cardiomyogenic fate in vivo. Proc Natl Acad Sci U S A 2007;104:17783-8.

85. Laflamme MA, Myerson D, Saffitz JE, Murry CE. Evidence for cardiomyocyte repopulation by extracardiac progenitors in transplanted human hearts. Circ Res 2002;90:634-40.

86. Hocht-Zeisberg E, Kahnert H, Guan K et al. Cellular repopulation of myocardial infarction in patients with sex-mismatched heart transplantation. Eur Heart J 2004;25:749-58.

87. Taylor DA, Atkins BZ, Hungspreugs $\mathrm{P}$ et al. Regenerating functional myocardium: improved performance after skeletal myoblast transplantation. Nat Med 1998;4:929-33.

88. Fujii T, Yau TM, Weisel RD et al. Cell transplantation to prevent heart failure: a comparison of cell types. Ann Thorac Surg 2003;76:2062-70.

89. Hutcheson KA, Atkins BZ, Hueman MT, Hopkins MB, Glower DD, Taylor DA. Comparison of benefits on myocardial performance of cellular cardiomyoplasty with skeletal myoblasts and fibroblasts. Cell Transplant 2000;9:359-68.

90. Murry CE, Reinecke H, Pabon LM. Regeneration gaps: Observations on stem cells and cardiac repair. J Am Coll Cardiol 2006;47:1777-85.

91. Wall ST, Walker JC, Healy KE, Ratcliffe MB, Guccione JM. Theoretical impact of the injection of material into the myocardium: A finite element model simulation. Circulation 2006;114:2627-35. 
92. Shantsila E, Watson T, Lip GY. Endothelial progenitor cells in cardiovascular disorders. J Am Coll Cardiol 2007;49:741-52.

93. Losordo DW, Schatz RA, White CJ et al. Intramyocardial transplantation of autologous CD34+ stem cells for intractable angina: a phase I/IIa double-blind, randomized controlled trial. Circulation 2007;115:3165-72.

94. Kinnaird T, Stabile E, Burnett MS et al. Marrow-derived stromal cells express genes encoding a broad spectrum of arteriogenic cytokines and promote in vitro and in vivo arteriogenesis through paracrine mechanisms. Circ Res 2004;94:67885 .

95. Gnecchi M, He H, Noiseux $\mathrm{N}$ et al. Evidence supporting paracrine hypothesis for Akt-modified mesenchymal stem cell-mediated cardiac protection and functional improvement. FASEB J 2006;20:661-9.

96. Thum T, Bauersachs J, Poole-Wilson PA, Volk HD, Anker SD. The dying stem cell hypothesis: immune modulation as a novel mechanism for progenitor cell therapy in cardiac muscle. J Am Coll Cardiol 2005;46:1799-802.

97. Solheim S, Seljeflot I, Lunde K et al. Inflammatory responses after intracoronary injection of autologous mononuclear bone marrow cells in patients with acute myocardial infarction. Am Heart J 2008;155:55-9.

98. Kinnaird T, Stabile E, Zbinden S, Burnett MS, Epstein SE. Cardiovascular risk factors impair native collateral development and may impair efficacy of therapeutic interventions. Cardiovasc Res 2008.

99. Beltrami CA, Finato N, Rocco M et al. Structural basis of end-stage failure in ischemic cardiomyopathy in humans. Circulation 1994;89:151-63.

100. Hofmann M, Wollert KC, Meyer GP et al. Monitoring of bone marrow cell homing into the infarcted human myocardium. Circulation 2005;111:2198-202.

101. Penicka M, Widimsky P, Kobylka P, Kozak T, Lang O. Early tissue distribution of bone marrow mononuclear cells after transcoronary transplantation in a patient with acute myocardial infarction. Circulation 2005;112:e63-e65.

102. Geng YJ. Molecular mechanisms for cardiovascular stem cell apoptosis and growth in the hearts with atherosclerotic coronary disease and ischemic heart failure. Ann N Y Acad Sci 2003;1010:687-97.

103. Fernandez-Aviles F, San Roman JA, Garcia-Frade J et al. Experimental and clinical regenerative capability of human bone marrow cells after myocardial infarction. Circ Res 2004;95:742-8.

104. Nadal-Ginard B, Fuster V. Myocardial cell therapy at the crossroads. Nat Clin Pract Cardiovasc Med 2007;4:1. 
105. Britten MB, Abolmaali ND, Assmus B et al. Infarct remodeling after intracoronary progenitor cell treatment in patients with acute myocardial infarction (TOPCARE-AMI): mechanistic insights from serial contrast-enhanced magnetic resonance imaging. Circulation 2003;108:2212-8.

106. Blocklet $\mathrm{D}$, Toungouz $\mathrm{M}$, Berkenboom $\mathrm{G}$ et al. Myocardial homing of non mobilized peripheral-blood CD34+ cells after intra-coronary injection. Stem Cells 2005;2005-0201.

107. Hou D, Youssef EA-S, Brinton TJ et al. Radiolabeled cell distribution after intramyocardial, intracoronary, and interstitial retrograde coronary venous delivery: Implications for current clinical trials. Circulation 2005;112:I-150.

108. Bartunek J, Wijns W, Heyndrickx GR, Vanderheyden M. Timing of intracoronary bone-marrow-derived stem cell transplantation after ST-elevation myocardial infarction. Nat Clin Pract Cardiovasc Med 2006;3 Suppl 1:S52-S56.

109. Muller-Ehmsen J, Krausgrill B, Burst V et al. Effective engraftment but poor midterm persistence of mononuclear and mesenchymal bone marrow cells in acute and chronic rat myocardial infarction. J Mol Cell Cardiol 2006;41:876-84.

110. Chen Sl, Fang Ww, Ye F et al. Effect on left ventricular function of intracoronary transplantation of autologous bone marrow mesenchymal stem cell in patients with acute myocardial infarction. Am J Cardiol 2004;94:92-5.

111. Vulliet PR, Greeley M, Halloran SM, MacDonald KA, Kittleson MD. Intracoronary arterial injection of mesenchymal stromal cells and microinfarction in dogs. Lancet 2004;363:783-4.

112. Breitbach M, Bostani T, Roell W et al. Potential risks of bone marrow cell transplantation into infarcted hearts. Blood 2007;110:1362-9.

113. Kastrup J, Ripa RS, Wang Y, Jorgensen E. Myocardial regeneration induced by granulocyte-colony-stimulating factor mobilization of stem cells in patients with acute or chronic ischaemic heart disease: a non-invasive alternative for clinical stem cell therapy? Eur Heart J 2006;27:2748-54.

114. Menasche $\mathrm{P}$, Alfieri $\mathrm{O}$, Janssens $\mathrm{S}$ et al. The myoblast autologous grafting in ischemic cardiomyopathy (MAGIC) trial. First randomized placebo-controlled study of myoblast transplantation. Circulation 2008;Published ahead of print on February 19, 2008.

115. Caspi O, Huber I, Kehat I et al. Transplantation of human embryonic stem cellderived cardiomyocytes improves myocardial performance in infarcted rat hearts. J Am Coll Cardiol 2007;50:1884-93. 
116. Laflamme MA, Chen KY, Naumova AV et al. Cardiomyocytes derived from human embryonic stem cells in pro-survival factors enhance function of infarcted rat hearts. Nat Biotech 2007;25:1015-24.

117. Nussbaum J, Minami E, Laflamme MA et al. Transplantation of undifferentiated murine embryonic stem cells in the heart: teratoma formation and immune response. FASEB J 2007.

118. Drukker M, Katz G, Urbach A et al. Characterization of the expression of MHC proteins in human embryonic stem cells. Proc Natl Acad Sci U S A 2002;99:9864-9.

119. Bonnevie L, Bel A, Sabbah L et al. Is xenotransplantation of embryonic stem cells a realistic option? Transplantation 2007;83:333-5.

120. Kennedy D. Editorial retraction. Science 2006;311:335.

121. Yu J, Vodyanik MA, Smuga-Otto K et al. Induced pluripotent stem cell lines derived from human somatic cells. Science 2007;318:1917-20.

122. Takahashi $\mathrm{K}$, Tanabe $\mathrm{K}$, Ohnuki $\mathrm{M}$ et al. Induction of pluripotent stem cells from adult human fibroblasts by defined factors. Cell 2007;131:861-72. 